\title{
Ghrelin and growth hormone serum levels during the clonidine test in children with short stature and variable growth hormone status
}

\author{
Charilaos Stylianou ${ }^{1}$, Assimina Galli-Tsinopoulou ${ }^{1}$, Maria G. Grammatikopoulou' ${ }^{1}$, \\ George Koliakos ${ }^{2}$, George Varlamis ${ }^{1}$ \\ ${ }^{1}$ Fourth Department of Pediatrics, ${ }^{2}$ Department of Biochemistry, Medical School, Aristotle University, Thessaloniki, \\ Greece
}

\begin{abstract}
OBJECTIVE: The exact role of ghrelin in the control of growth hormone (GH) secretion has not been completely clarified as yet. The aim of the present study was 1) to investigate the effect of a substance promoting GH secretion (clonidine) on ghrelin levels in children with short stature with growth hormone deficiency (GHD) and normal growth hormone (NGH), and 2) to assess possible correlations between GH and ghrelin values during the clonidine test. DESIGN: Eighteen prepubertal children with short stature were included in the study. Using the results of two GH-provocative tests (glucagon and clonidine), the participants were divided into two groups: GHD and NGH. In both groups, ghrelin levels were determined during the clonidine stimulation test. RESULTS: Different responses regarding ghrelin levels during the clonidine stimulation test were observed in the two study groups (GHD and NGH). A decrease in ghrelin levels was observed in the NGH children accompanied by a rise in the circulating GH levels, whereas the GHD children demonstrated a rise in both ghrelin and GH levels. CONCLUSIONS: The data indicate an inverse relationship between circulating ghrelin and GH in NGH children, suggesting the presence of a negative feedback loop between ghrelin and GH. Analogous changes were not observed in GHD children.
\end{abstract}

Key words: Clonidine, Ghrelin, Growth, Growth hormone, Growth hormone deficiency, Short stature

\section{INTRODUCTION}

Ghrelin is a 28 amino-residue peptide produced Address for correspondence:

Charilaos Stylianou, $4^{\text {th }}$ Department of Pediatrics, Aristotle University of Thessaloniki, Papageorgiou General Hospital, Ring Road, Nea Efkarpia, GR-56403 Thessaloniki, Greece; Tel.: +30 2310 991537; Fax: +30 2310 991535; E-mail: chstylianou@gmail.com

Received 30-01-10, Revised 10-07-10, Accepted 11-10-10 mainly in the stomach. ${ }^{1}$ Among its several endocrine activities, ghrelin also exerts orexigenic and adipogenic effects by modulating the expression of orexigenic and anorexigenic neuropeptides in the hypothalamus. ${ }^{2-4}$ Ghrelin was initially identified as the endogenous ligand of the growth hormone secretagogue (GHS) receptor type 1a (GHS-R1a), possessing a strong growth hormone-releasing activity. ${ }^{5,6} \mathrm{GHS}$ receptors 
are present in the hypothamulus and the pituitary. ${ }^{7,8}$ In addition, ghrelin potentiates the growth hormone releasing hormone $(\mathrm{GHRH})$-dependent secretion of growth hormone $(\mathrm{GH}){ }^{9}$

In general, the GH-releasing effect of ghrelin appears to result from several actions such as the ghrelin binding to GHSR-1a on the somatotrophic cells in the pituitary, ${ }^{8}$ the ghrelin-induced activation of GHRHcontaining neurons, the inhibition of somatostatincontaining neurons in the hypothalamus ${ }^{10}$ and also the activation of vagal afferents. ${ }^{11}$

Nevertheless, the exact role of ghrelin in the control of GH secretion has not yet been clarified. Many studies have been conducted in short-stature children in order to assess the presence of a negative feedback loop between GH/IGF-1 axis and ghrelin using different $\mathrm{GH}$ provocative tests, with variable results. ${ }^{12-15}$ The variability in the results might be attributed, at least in part, to the fact that ghrelin secretion is closely associated with glucose metabolism, ${ }^{16}$ thus the use of insulin or glucagon for GH stimulation may be unsuitable. Clonidine, on the other hand, which has not thus far been used in studies assessing the relationship between ghrelin and $\mathrm{GH}$, could represent a more appropriate stimulus, since it does not affect glucose metabolism. ${ }^{17}$

Therefore, the present study was designed to investigate: 1) the effect of clonidine on ghrelin levels in short-stature children with or without growth hormone deficiency and 2) to uncover possible correlations of circulation $\mathrm{GH}$ with ghrelin throughout the clonidine test.

\section{PATIENTS AND METHODS}

\section{Patients}

Eighteen children (11 boys and 7 girls), aged $9.7 \pm 2.6($ mean $\pm \mathrm{SD})$ years, with short stature were studied. The participants were recruited from the outpatient unit of the $4^{\text {th }}$ Department of Pediatrics, of the Aristotle University Medical School, Thessaloniki, Greece. Inclusion criteria were absence of chronic disease or intrauterine growth retardation, no drug therapy and an unremarkable family and personal medical history.

Body weight and height were measured in duplicate using a Seca weighing-scale (Seca 711) and a stadiometer (Harpenden, Baty International, Essex, UK), respectively. Standard deviation score (SDS) as well as body mass index (BMI) z-scores were calculated using the growth charts suggested by Kuczmarski et al. ${ }^{18}$

Physical examination was normal and pubertal stage was Tanner I (prepubertal). ${ }^{19,20}$ The standard laboratory tests (full blood count, routine biochemical analysis including renal, liver and thyroid function) did not demonstrate any abnormality. Coeliac disease was excluded by normal values of anti-endomysium, anti-transglutaminase and anti-gliadin antibodies. Brain magnetic resonance imaging (MRI) was performed in all patients.

The study was approved by the Scientific Ethics Committee of the Aristotle University's Medical School. Informed written consent was obtained from parents and guardians of all participants prior to the investigation.

\section{Procedure}

Glucagon and clonidine stimulation tests $(0.03$ $\mathrm{mg} / \mathrm{kg}$ of body weight IM, max $1 \mathrm{mg}$ and $0.150 \mathrm{mg} /$ $\mathrm{m}^{2}$ orally, max $0.3 \mathrm{mg}$, respectively) were performed in all participants for GH assessment. ${ }^{21,22}$ Ten of the children were diagnosed with growth hormone deficiency (GHD) using a peak GH cut-off value of $10 \mu \mathrm{g} / \mathrm{l}$. Thus, the sample included two groups: the GHD ( $n=10)$ and the normal growth hormone (NGH) $(n=8)$. Besides $\mathrm{GH}$ levels, ghrelin levels were additionally measured during the clonidine stimulation test.

At 08:30, following an overnight fast, an intravenous catheter was placed in the anticubital vein (half an hour prior to the study in order to avoid the stress from venepuncture). During the clonidine test blood samples were drawn at baseline and 30, 60, 90 and 120 min after ingestion of clonidine for $\mathrm{GH}$ and ghrelin measurement. Throughout the procedure blood pressure was strictly monitored. Blood samples were then centrifuged (10 min at $1500 \mathrm{~g}$ ) and the aliquots were stored at $-20^{\circ} \mathrm{C}$, until ghrelin was assayed according to the instructions suggested by Gröschl et $\mathrm{al}^{23}$ IGF-1 levels were also measured at baseline.

All anthropometric and metabolic parameters of the study population are presented in Table 1. 
Table 1. Anthropometric and metabolic parameters of the study population (mean $\pm \mathrm{SD})$

\begin{tabular}{lccc}
\hline & $\begin{array}{c}\text { GHD } \\
(\mathbf{n = 1 0})\end{array}$ & $\begin{array}{c}\text { NGH } \\
(\mathbf{n = 8})\end{array}$ & P value \\
\hline Boys/girls (n) & $6 / 4$ & $5 / 3$ & \\
Age (years) & $9.9 \pm 0.7$ & $9.5 \pm 1.1$ & 0.758 \\
Body weight $(\mathrm{kg})$ & $34.4 \pm 3.3$ & $29.5 \pm 4.6$ & 0.389 \\
Height $(\mathrm{cm})$ & $124.7 \pm 6.5$ & $125.5 \pm 4.5$ & 0.377 \\
Height SDS & $-2.06 \pm 0.59$ & $-1.42 \pm 0.77$ & 0.071 \\
BMI z-score & $0.99 \pm 1.03$ & $0.44 \pm 1.81$ & 0.561 \\
GH peak ( $\mu \mathrm{g} / \mathrm{l})$ & $4.6 \pm 3.5$ & $14.2 \pm 2.4$ & 0.001 \\
Ghrelin 0 $(\mathrm{pmol} / \mathrm{l})$ & $699.8 \pm 79.9$ & $620.2 \pm 66.2$ & 0.469 \\
Ghrelin peak $(\mathrm{pmol} / \mathrm{l})$ & $1224.9 \pm 539.0$ & $680.2 \pm 112.1$ & 0.013 \\
\hline
\end{tabular}

BMI: Body mass index; GH: Growth hormone; IGF-1: Insulinlike growth factor-1; GHD: growth hormone deficiency; NGH: normal growth hormone.

\section{Assays}

$G H$

Serum GH was measured by immunoradiometric assay (IRMA) - DPC Immulite 2000, using reagents purchased from Diagnostics Products Corporation, Gwynned, UK, with Coefficients of Variation (CV) $<7 \%$ and lower detection limits $0.01 \mu \mathrm{g} / \mathrm{l}$.

\section{$I G F-1$}

Serum IGF-1 was measured by IRMA using reagents purchased from Diagnostic Systems Laboratories, Texas, USA. Sensitivity, intra-assay coefficients of variation (CV) and inter-assay CV were $0.03 \mu \mathrm{g} / \mathrm{l}$, $4.5-7.1 \%$ and $4.8-8.8 \%$, respectively.

\section{Ghrelin}

Serum ghrelin was measured by a commercial radioimmunoassay kit (Phoenix Pharmaceuticals, Inc. Belmont, CA, USA). This assay uses a ${ }^{125} \mathrm{I}-$ labeled ghrelin tracer and a rabbit polyclonal antibody against full-length, octanoylated human ghrelin that recognizes the acylated and des-acyl forms. The antiserum does not cross-react with any relevant peptide according to the information provided by the manufacturer. The lower and upper detection limits were 23.7 and $739.6 \mathrm{pmol} / \mathrm{l}$, respectively. The intra- and interassay coefficients of variation (CV) were $5.30 \%$ and $13.61 \%$, respectively.

\section{Statistical analyses}

All statistical analyses were performed with SPSS software, v. 15.0 (SPSS Inc, Chicago, Illinois). Normal distribution was assessed with the KolmogorovSmirnov test and statistical significance level was set at 5\% (2-tailed). All data were normally distributed.

Differences between GHD and NGH children were assessed via the independent samples t-test. Changes in each time interval as compared with baseline during the clonidine stimulation test were evaluated with paired samples t-tests. Correlations were assessed by calculation of the Pearson's coefficient. Figures were plotted with Origin 7.0 SRO (Origin Lab Corporation, Northampton, MA, USA).

\section{RESULTS}

\section{Baseline values and changes during the clonidine test}

No differences were observed in age, BMI z-score, height SDS and ghrelin levels between the two groups. GH peak values were significantly higher and ghrelin peak values were lower in the NGH children compared to the GHD participants ( $\mathrm{p}=0.001$ and 0.013 , respectively) (Table 1).

Subjects with GHD demonstrated a significant



Figure 1. Mean $\pm \mathrm{SD}$ values of serum ghrelin during the clonidine test in the two groups. Significantly different from baseline using paired t-test $(\dagger \uparrow \mathrm{p}=0.01, \uparrow \mathrm{p}=0.05)$. Significantly different from the previous time interval using paired t-test $(\ddagger p=0.05)$. Significantly different from the NGH group using independent t-test $(* * \mathrm{p}=0.01 ; * * * \mathrm{p}=0.001)$. 
fall in serum ghrelin concentration at $90 \mathrm{~min}$ and a rise at $120 \mathrm{~min}$ ( $\mathrm{p}=0.02$ for both) compared to the previous time interval (Figure 1). In the NGH group, circulating ghrelin was significantly lower at $30 \mathrm{~min}$ and $90 \mathrm{~min}$ compared to baseline $(\mathrm{p}=0.009$ and 0.007 , respectively). Between the two studied groups, ghrelin levels were significantly higher in the GHD group at all time intervals with a $p$ value of 0.007 at $30 \mathrm{~min}, 0.001$ at $60 \mathrm{~min}, 0.002$ at $90 \mathrm{~min}$ and 0.007 at $120 \mathrm{~min}$ post-clonidine administration. Individual and group fluctuations in circulating ghrelin are presented in Table 2.

Mean GH and ghrelin fluctuations within each group are demonstrated in Figure 2. GH concentration was higher in the NGH participants at $60 \mathrm{~min}$ and 90 $\min (\mathrm{p}=0.011$ and $\mathrm{p}=0.001$, respectively) compared to the GHD children. GH levels significantly rose at $90 \min (p=0.003)$ in the GHD participants and at all time intervals after $60 \mathrm{~min}$ in the $\mathrm{NGH}$ participants, compared to baseline ( $p=0.009,0.003$ and 0.041 at 60,90 and $120 \mathrm{~min}$, respectively).

\section{Correlations}

The absolute body weight $(\mathrm{kg})$ was negatively correlated with the baseline ghrelin levels $(\mathrm{r}=-0.867$, $\mathrm{p}<0.001)$, and to the baseline $\mathrm{GH}$ concentration ( $\mathrm{r}=-$ $0.787, p=0.018$ ) only in NGH participants. In the NGH group, IGF-1 demonstrated a strong correlation with the height-SDS $(r=0.843, p=0.009)$. The same group exhibited a negative relationship between baseline ghrelin and GH ( $r=-0.767, p=0.026)$. No correlations were observed between ghrelin and $\mathrm{GH}$ changes at the same time point. Ghrelin levels at $60 \mathrm{~min}$ were significantly negatively correlated with $\mathrm{GH}$ levels at $90 \mathrm{~min}$ in the NGH participants $(\mathrm{r}=-0.735, \mathrm{p}=0.001)$, indicating that a decline in ghrelin concentration precedes the increases in $\mathrm{GH}$ in this group.

\section{DISCUSSION}

The study population included short prepubertal children (with and without GHD). The selected prepubertal stage was chosen in order to avoid possible

Table 2. Individual and group ghrelin levels (pmol/l)

\begin{tabular}{|c|c|c|c|c|c|}
\hline \multirow[b]{2}{*}{ Participant } & \multicolumn{5}{|c|}{ Time after administration of clonidine (min) } \\
\hline & $\mathbf{0}$ & 30 & 60 & 90 & 120 \\
\hline GHD \#1 & 1227.3 & 1151.3 & 677.4 & 737.8 & 778.4 \\
\hline GHD \#2 & 589.3 & 690.0 & 618.2 & 465.4 & 409.8 \\
\hline GHD \#3 & 524.7 & 234.9 & 382.0 & 182.7 & 284.7 \\
\hline GHD \#4 & 583.5 & 991.7 & 956.1 & 811.4 & 1843.4 \\
\hline GHD \#5 & 740.2 & 607.4 & 903.9 & 759.2 & 1271.6 \\
\hline GHD \#6 & 747.3 & 602.6 & 685.6 & 785.3 & 1276.4 \\
\hline GHD \#7 & 310.8 & 491.1 & 899.2 & 605.0 & 2351.1 \\
\hline GHD \#8 & 801.9 & 707.0 & 830.4 & 614.5 & 875.4 \\
\hline GHD \#9 & 546.9 & 876.5 & 765.3 & 689.7 & 978.7 \\
\hline GHD \#10 & 926.2 & 656.0 & 821.6 & 765.5 & 1210.7 \\
\hline NGH \#1 & 813.2 & 305.6 & 252.4 & 504.8 & 335.8 \\
\hline NGH \#2 & 218.6 & 215.3 & 537.2 & 261.7 & 400.6 \\
\hline NGH \#3 & 827.1 & 569.6 & 407.5 & 252.4 & 289.4 \\
\hline NGH \#4 & 664.7 & 204.0 & 185.1 & 130.5 & 244.4 \\
\hline NGH \#5 & 618.9 & 624.0 & 664.3 & 540.9 & 780.5 \\
\hline NGH \#6 & 625.5 & 378.5 & 407.3 & 336.4 & 411.3 \\
\hline NGH \#7 & 573.5 & 428.3 & 489.6 & 365.5 & 520.7 \\
\hline NGH \#8 & 620.1 & 345.4 & 287.5 & 330.3 & 435.6 \\
\hline GHD $($ mean $\pm \mathrm{SD})$ & $699.8 \pm 252.7$ & $700.9 \pm 258.2^{* *}$ & $754.0 \pm 170.7^{* * *}$ & $641.6 \pm 192.6 \ddagger^{* *}$ & $1128.0 \pm 623.0 \ddagger^{* *}$ \\
\hline $\mathrm{NGH}($ mean $\pm \mathrm{SD})$ & $620.2 \pm 187.3$ & $383.8 \pm 152.4 \dagger \dagger$ & $403.8 \pm 159.2$ & $340.3 \pm 134.2 \dagger \dagger$ & $427.3 \pm 167.1$ \\
\hline
\end{tabular}

GHD: growth hormone deficiency; NGH: normal growth hormone.

Significantly different from baseline using paired t-test $\uparrow \mathrm{p}=0.05$ and $\uparrow \uparrow \mathrm{p}=0.01$. Significantly different from the previous time interval using paired t-test $(\ddagger \mathrm{p}=0.05)$. Significantly different from the NGH group using independent t-test $\left(* * \mathrm{p}=0.01 ;{ }^{* * *} \mathrm{p}=0.001\right)$. 

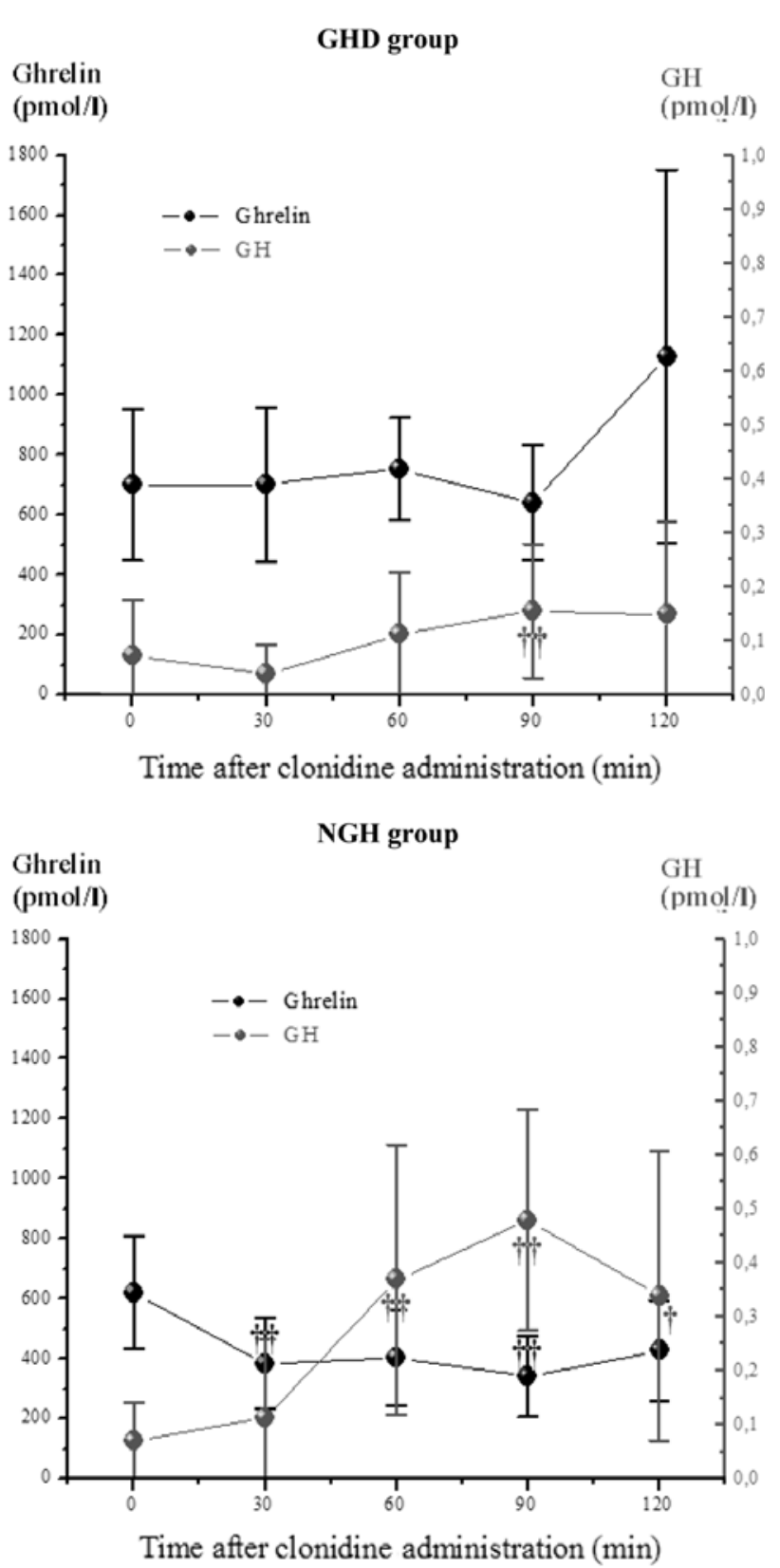

Figure 2. Serum ghrelin and $\mathrm{GH}$ values (mean $\pm \mathrm{SD}$ ) during the clonidine test in the two groups. Significantly different from baseline using paired t-test $(\dagger \dagger \mathrm{p}=0.01, \uparrow \mathrm{p}=0.05)$.

To convert $\mathrm{GH}$ values from $\mathrm{pmol} / \mathrm{l}$ to $\mu \mathrm{g} / \mathrm{l}$, divide by 0.0465 .

influence of puberty, which has been found to affect ghrelin levels. ${ }^{24}$ According to our findings, clonidine ingestion induced different trends in the ghrelin levels in the GHD and NGH groups. Overall, ghrelin levels were higher in the GHD group compared to the NGH participants at all intervals after clonidine intake, but not at baseline. This observation is diffi- cult to interpret but it may represent a compensatory mechanism for the low $\mathrm{GH}$ values through a negative GH-ghrelin loop effect.

There is scant information regarding the participation of ghrelin in the control of GH secretion. Although pituitary ghrelin appears to be involved in the $\mathrm{GH}$ release, ${ }^{25}$ studies in patients with short stature of various etiology, using different $\mathrm{GH}$ provocative tests, have demonstrated conflicting results regarding the presence of a negative feedback between GH and ghrelin. ${ }^{12-15}$ Two studies ${ }^{12,26}$ have suggested an inverse relationship between circulating $\mathrm{GH}$ and ghrelin levels, indicating the existence of a feedback loop. Hirsh et al failed to relate ghrelin levels to the post-glucagon administration $\mathrm{GH}$ release, a finding explained by the authors as a result of the suppressed ghrelin exhibited after glucagon administration. ${ }^{15}$ According to Janssen et al, GH replacement therapy for one year failed to alter the circulating ghrelin levels in subjects with GHD. ${ }^{14}$ However, long-term treatment with recombinant human $\mathrm{GH}$ was found to be associated with a significant reduction in the $\mathrm{BMI}$ and \%BF in GHD patients, and hence the attenuated ghrelin levels might be the result of altered body fat stores. ${ }^{26}$

The present study demonstrated different ghrelin$\mathrm{GH}$ responses in the two study groups. In accordance with Matsuoka et al, ${ }^{12}$ an inverse association was noted between circulating $\mathrm{GH}$ and ghrelin levels in the $\mathrm{NGH}$ participants, indicating the presence of a negative feedback loop between GH and ghrelin. Moreover, $\mathrm{NGH}$ participants exhibited a decline in total ghrelin concentration prior to the GH peak. Thus, an inverse relationship between ghrelin at $60 \mathrm{~min}$ and $\mathrm{GH}$ at 90 min was detected in the NGH group. This finding indicates that in NGH children, the rise in GH levels is associated with a decline in the circulating ghrelin values. It is possible that a feedback phenomenon occurs, ghrelin being suppressed by the rise in $\mathrm{GH}$ provoked by clonidine, although other mechanisms may be operative.

According to Maghnie et al, ${ }^{27}$ children and adults with GHD demonstrate a rise in GH levels following an increase in the circulating ghrelin. The same investigators, using brain MRI, also demonstrated that $\mathrm{GH}$ response to ghrelin requires the functional 
and anatomical integrity of hypothalamic-pituitary connections (intact pituitary stalk) and that the degree of the $\mathrm{GH}$ response to the releasing peptide might predict the degree of functional impairment of hypothalamic-pituitary connections. In our study population, brain MRI did not reveal any hypothalamic-pituitary abnormalities.

The negative relationship between baseline ghrelin and body weight observed in the NGH participants has also been noted by other researchers in children with idiopathic short stature. ${ }^{28,29}$ This phenomenon has been explained as ghrelin's compensatory mechanism to change the metabolic process. ${ }^{29,30}$ Since this relationship was only observed in NGH children, it is possible that the reduced GH levels in the GHD participants prohibits physiological ghrelin secretion and results in a different relationship between ghrelin and body weight in this group.

Certain limitations of the present study must be mentioned. First of all, the number of patients included was relatively small. Secondly, we did not perform a clonidine stimulation test on a group of prepubertal children with normal stature. This was not carried out for ethical reasons. Thirdly, the duration of the oral clonidine test is not standardized, the duration varying from $90-180 \mathrm{~min}$ in different studies. ${ }^{31}$ This inconsistency might explain the variable results obtained in different studies.

IGF-1 has been reported to be one of the most significant determinants of ghrelin secretion during childhood and adolescence, ${ }^{32}$ as serum ghrelin and IGF-1 concentrations are negatively correlated in healthy children ${ }^{33}$ and children with idiopathic short stature. ${ }^{34}$ However, our study failed to demonstrate the existence of a relationship between ghrelin and IGF-1, possibly due to the small number of participants involved.

In conclusion, our findings indicate an inverse relationship between ghrelin and GH in NGH children suggesting the existence of a GH-ghrelin feedback loop. Analogous interrelationship was not observed in the GHD children, indicating that the GH status possibly determines the relationship between circulating levels of ghrelin and GH. Further studies are required to better define the relationship between ghrelin and $\mathrm{GH}$ and the underlying mechanisms.

\section{ACKNOWLEDGMENTS}

The authors wish to express their gratitude to Dr Patricia Crofton, Department of Paediatric Biochemistry, Royal Hospital for Sick Children, University of Edinburgh, for her helpful comments during the preparation of the manuscript.

\section{REFERENCES}

1. Kojima M, Hosoda H, Date Y, Nakazato M, Matsuo H, Kangawa K, 1999 Ghrelin is a growth hormone-releasing acylated peptide from stomach. Nature 402: 656-660.

2. Wren AM, Seal LJ, Cohen MA, et al, 2001 Ghrelin enhances appetite and increases food intake in humans. J Clin Endocrinol Metab 86: 5992-5995.

3. Tschöp M, Smiley DL, Heiman ML, 2000 Ghrelin induces adiposity in rodents. Nature; 407: 908-913.

4. Kamegai J, Tamura H, Shimizu T, Ishii S, Sugihara H, Wakabayashi I, 2001 Chronic central infusion of ghrelin increases hypothalamic neuropeptide Y and Agoutirelated protein mRNA levels and body weight in rats. Diabetes 50: 2438-2443.

5. Kojima M, Hosoda H, Matsuo H, Kangawa K, 2001 Ghrelin: discovery of the natural endogenous ligand for the growth hormone secretagogue receptor. Trends Endocrinol Metab 12: 118-122.

6. Arvat E, DiVito L, Broglio F, et al, 2000 Preliminary evidence that ghrelin, the natural GH secretagogue (GHS)-receptor ligand, strongly stimulates GH secretion in humans. J Endocrinol Invest 23: 493-495.

7. Howard AD, Feighner SD, Cully DF, et al, 1996 A receptor in pituitary and hypothalamus that functions in growth hormone release. Science 273: 974-977.

8. Malagon MM, Luque RM, Ruiz-Guerrero E, et al, 2003 Intracellular signalling mechanisms mediating ghrelinstimulated growth hormone release in somatotropes. Endocrinology 144: 5372-5380.

9. Hataya Y, Akamizu T, Takaya K, et al, 2001 A low dose of ghrelin stimulates growth hormone $(\mathrm{GH})$ release synergistically with GH-releasing hormone in humans. J Clin Endocrinol Metab 86: 4552.

10. Popovic V, Miljic D, Micic D, et al, 2003 Ghrelin main action on the regulation of growth hormone release is exerted at hypothalamic level. J Clin Endocrinol Metab 88: 3450-3453.

11. Burdyga G, Varro A, Dimaline R, Thompson DG, Dockray GJ, 2006 Ghrelin receptors in rat and human nodose ganglia: putative role in regulating $\mathrm{CB}-1$ and $\mathrm{MCH}$ receptor abundance. Am J Physiol Gastrointest Liver Physiol 290: 1289-1297.

12. Matsuoka H, Hosoda H, Sugawara H, et al, 2005 Shortterm secretory regulation of ghrelin during provocative tests in prepubertal children with various growth hormone secretory capacities. Horm Res 64: 274-279. 
13. Caminos JE, Seoane LM, Tovar SA, Casanueva FF, Dieguez C, 2002 Influence of thyroid status and growth hormone deficiency on ghrelin. Eur J Endocrinol 147: 159-163.

14. Janssen JA, van der Toorn FM, Hofland LJ, et al, 2001 Systemic ghrelin levels in subjects with growth hormone deficiency are not modified by one year of growth hormone replacement therapy. Eur J Endocrinol 145: 711-716.

15. Hirsh D, Heinrichs C, Leenders B, Wong A, Cummings $\mathrm{D}$, Chanoine J, 2005 Ghrelin is suppressed by glucagon and does not mediate glucagon-related growth hormone release. Horm Res 63: 111-118.

16. Galli-Tsinopoulou A, Stylianou C, Farmakiotis D, Rousso I, Karamouzis M, Nousia-Arvanitakis S, 2007 Ghrelin serum levels during oral glucose tolerance test in prepubertal obese children with insulin resistance. J Pediatr Endocrinol Metab 20: 1085-1092.

17. Lanes R, Hurtado E, 1982 Oral clonidine-an effective growth hormone-releasing agent in prepubertal subjects. J Pediatr 100: 710-714.

18. Kuczmarski RJ, Odgen CL, Grummer-Strawn LM, et al, 2000 CDC growth charts: United States. Adv Data 134: 1-27.

19. Marshall WA, Tanner JM, 1969 Variations in pattern of pubertal changes in girls. Arch Dis Child 44: 291-303.

20. Marshall WA, Tanner JM, 1970 Variations in pattern of pubertal changes in boys. Arch Dis Child 45: 13-23.

21. Sizonenko P, Clayton P, Cohen P, Hintz R, Tanaka T, Laron Z, 2001 Diagnosis and management of growth hormone deficiency in childhood and adolescence. Growth Hormone IGF Res 11: 137-165.

22. Lanes R, Recker B, Fort P, Lifshitz F, 1985 Low dose oral clonidine: a simple and reliable growth hormone screening test for children. Am J Dis Child 139: 87-89.

23. Gröschl M, Wagner R, Dötsch J, Rascher W, Rauh M, 2002 Preanalytical influences on the measurement of ghrelin. Clin Chem 48: 1114-1116.

24. Soriano-Guillen L, Barrios V, Chowen JA, et al, 2004 Ghrelin levels from fetal life through early adulthood: relationship with endocrine and metabolic and anthropometric measures. J Pediatr 144: 30-35.

25. Kamegai J, Tamura H, Shimizu T, et al, 2004 The Role of Pituitary Ghrelin in Growth Hormone (GH) Secretion: GH-Releasing Hormone-Dependent Regulation of Pituitary Ghrelin Gene Expression and Peptide Content. Endocrinology 145: 3731-3738.

26. Giavoli C, Cappiello V, Corbetta S, et al, 2004 Different effects of short- and long-term recombinant hGH administration on ghrelin and adiponectin levels in GH-deficient adults. Clin Endocrinol (Oxf) 61: 81-87.

27. Maghnie M, Pennati MC, Civardi E, et al 2007 GH response to ghrelin in subjects with congenital $\mathrm{GH}$ deficiency: evidence that ghrelin action requires hypothalamic-pituitary connections. Eur J Endocrinol 156: 449-454.

28. Camurdan MO, Bideci A, Demirel F, Cinaz P, 2006 Serum ghrelin, IGF-1 and IGFBP-3 levels in children with normal variant short stature. Endocr J 53: 479-484.

29. Cummings DE, 2006, Ghrelin and the short- and longterm regulation of appetite and body weight. Physiol Behav 89: 71-84.

30. Dimaraki EV, Jaffe CA, 2006, Role of endogenous ghrelin in growth hormone secretion, appetite regulation and metabolism. Rev Endocr Metab Disord 7: 237-249.

31. Galluzzi F, Stagi S, Parpagnoli M, et al, 2006 Oral clonidine provocative test in the diagnosis of growth hormone deficiency in childhood: should we make the time uniform? Horm Res 66: 285-288.

32. Whatmore AJ, Hall CM, Jones J, Westwood M, Clayton PE, 2003 Ghrelin concentrations in healthy children and adolescents. Clin Endocrinol 59: 649-654.

33. Jarkovská Z, Rosická M, Marek J, et al, 2006 Plasma levels of total and active ghrelin in acromegaly and 